Sains Malaysiana 50(9)(2021): 2833-2846

http://doi.org/10.17576/jsm-2021-5009-26

\title{
Predicting Index Price Based on the COVID-19 Cases and Deaths
}

(Peramalan Harga Indeks berasaskan Kes dan Kematian COVID-19)

\author{
NUR SABRINA RAZALI \& R. NUR-FIRYAL*
}

\begin{abstract}
COVID-19 pandemic has impacted global financial market. In this paper, we study the impact of COVID-19 pandemic on four countries indexes which are United Kingdom, United States, Japan and Malaysia to see the effect of the spread of the virus on economy. Based on descriptive analysis, most index market suffer for a short period of time after the World Health Organization (WHO) declared COVID-19 as a pandemic on 11 March 2020. However, most markets manage to get back on track after a few months. We want to see the effect of number of COVID-19 cases and deaths on the index price because we believe that they will impact the economic growth of most countries. This will indirectly impact the countries index market as most businesses could not operate in full scale. Moreover, an increase in number of cases, most countries had to implement a partial or total lockdown which then impact the economic growth. Based on our studies, we conclude that the number of COVID-19 cases and deaths did have an impact on the four countries index price. Prediction analysis shows that the time series linear model can predict index price better than ARIMA model that relies on historical data. As of right now, COVID-19 does have a huge impact on the countries financial market and economic growth.
\end{abstract}

Keywords: ARIMA Model; COVID-19; predictive analysis; time series linear model

ABSTRAK

Pandemik COVID-19 memberi kesan kepada pasaran kewangan global. Dalam penyelidikan ini, kami mengkaji kesan pandemik COVID-19 kepada empat indeks negara iaitu United Kingdom, Amerika Syarikat, Jepun dan Malaysia untuk melihat kesan penyebaran virus ini terhadap ekonomi dan kewangan negara. Berdasarkan analisis deskriptif, kebanyakan pasaran indeks mengalami kerugian dalam jangka masa pendek terutama setelah Pertubuhan Kesihatan Sedunia (WHO) mengisytiharkan COVID-19 sebagai wabak pada 11 Mac 2020. Namun, kebanyakan harga pasaran meningkat semula setelah beberapa bulan. Dalam kajian ini, kami ingin melihat kesan jumlah kes dan kematian COVID-19 pada harga indeks kerana kami percaya bahawa ini akan mempengaruhi pertumbuhan ekonomi kebanyakan negara. Ini secara tidak langsung akan mempengaruhi pasaran indeks negara kerana kebanyakan perniagaan tidak dapat beroperasi dalam skala penuh. Peningkatan jumlah kes juga menyebabkan kebanyakan negara harus melaksanakan penyekatan kepada rakyat dan perniagaan yang mempengaruhi pertumbuhan ekonomi. Berdasarkan kajian ini, kami menyimpulkan bahawa jumlah kes dan kematian COVID-19 mempunyai kesan terhadap harga indeks keempat-empat negara. Analisis ramalan menunjukkan bahawa model linear siri masa dapat meramalkan harga indeks lebih baik daripada model ARIMA yang hanya bergantung kepada data masa lampau. COVID-19 mempunyai kesan besar terhadap pertumbuhan pasaran kewangan dan ekonomi negara.

Kata kunci: Analisis ramalan; COVID-19; model ARIMA; model linear siri masa

\section{INTRODUCTION}

The infectious disease of Novel Coronavirus (2019nCOV) or COVID-19 first emerged in December 2019 in Wuhan City, Hubei Province of China (WHO 2020). It quickly got the attention of the world due to its vast spread in January 2020 compared to the other kinds of flu or viruses. On $11^{\text {th }}$ March 2020, COVID-19 was declared as a global pandemic by WHO and more than 170 countries are 
affected by the disease (WHO 2020). As of November 30, the number of COVID-19 positive cases worldwide have been reported around 99.06 million, with 53.1 million recovered and 2.12 million global fatalities.

The response of Chinese government towards the new virus was to implement a total lockdown of the center of the diseases in Wuhan. Even though, this is later proved to be an effective measure of controlling the pandemic in China, other countries that were affected by these diseases suffer at a higher rate once the virus spread. The virus has a significant impact on the short-term global economic growth as countries need to go strict quarantine policies that will limit their economic activities. This effect will impact long-term economic from increasing number of unemployment and business failures due to lockdown and strict policies (Zhang et al. 2020).

COVID-19 disease resulted in a collapse of crude oil and crashed the stock market globally (Mazur et al. 2020). Other industries such as aviation, tourism, entertainment and real estate were effected negatively during these period. Preventive measures such as social distancing, self-quarantine and lockdowns have affected the economic losses and automatically affected the global stock markets.

Numbers of recent studies attempt to access the impact of the COVID-19 outbreak on the stock market. A study that provides a review on the socioeconomic effects of COVID-19 on individual aspects of the world economy (Nicola et al. 2020), study to analyse the reasons why the U.S. stock market reacted so much more adversely to COVID-19 than to previous pandemics that occurred in 1918-1919, 1957-1958 and 1968 (Baker et al. 2020). A picture of post-COVID-19 economic world study (Wagner 2020) and study the effect of policy announcements on the stock market during the early period of the pandemic (Cox et al. 2020).

The number of COVID-19 cases has negative significant impact on the global financial market in terms of returns and volatility especially to the countries that have high number of cases (Erdem 2020). Topcu and Gulal (2020) shows that the impact of COVID-19 for emerging stock market decline at the middle of March and begun to taper-off by mid-April.

Government intervention such as lockdown, work from home requirement does impact the economic activity and stock market performance in the Malaysia (Keh \& Tan 2020). While some sectors such as food and beverages were not impacted by the pandemic, other sector such as transportation and banks were highly impacted because of COVID-19. This can be seen from the high stock market volatility after the announcement (Engelhardt et al. 2021; Yagli 2021).

Stock prices are not randomly generated values rather they can be treated as a discrete time series model and its trend can be analysed accordingly, hence can also be forecasted. A system that can identify which countries are doing well and which countries are not in the dynamic stock market will make it easy for investors, market or finance professionals make decisions.

The two objectives were to identify whether daily COVID-19 number of cases and deaths influence the daily index price for four indexes representing four countries - USA, UK, Japan, and Malaysia and second we want to use the models to make prediction on the index value for the next 20 days by using two different models which are ARIMA and linear model. Both models assume time series data.

\section{Materials AND Methods}

DATA

Table 1 shows stock index related to each country and the first confirm case. S\&P 500 Index to represent the USA, FTSE 100 Index represent UK, Nikkei 225 Index represent Japan and KLCI Index represent Malaysia.

TABLE 1. Stock market indices and first confirmed case date

\begin{tabular}{ccc}
\hline Country & Index & First confirmed case \\
\hline USA & S\&P 500 & 22 $2^{\text {nd }}$ January 2020 \\
UK & FTSE 100 & $31^{\text {st }}$ January 2020 \\
Japan & Nikkei 225 & $22^{\text {nd }}$ January 2020 \\
Malaysia & KLCI & $28^{\text {th }}$ January 2020 \\
\hline
\end{tabular}


The mentioned indices are arguably the most representative indices of these countries' stock markets in the world press. The reason why these four indices are chosen to represent: USA which rank the top in the number of confirmed cases, UK to represent European country, Japan to represent one of the countries that manage to handle COVID-19 and Malaysia represents one of the developing countries.
The World Health Organization (WHO) declared COVID-19 as a global pandemic on $11^{\text {th }}$ March 2020 after the first case happen on $31^{\text {st }}$ December 2019. The data for the daily closing value and daily return of each of these indices for the period of $1^{\text {st }}$ January 2020 to $30^{\text {th }}$ November 2020 are collected from investing.com (Investing 2020) and converted into a time series data. The variables in this study are as in Table 2 .

TABLE 2. Variable description

\begin{tabular}{ccl}
\hline Variable name & Variable type & Description \\
\hline Closing price & Dependent variable & Daily closing price of the index \\
New cases & Independent variable & Frequency of daily positive cases \\
New deaths & Independent variable & Frequency of daily fatal cases \\
\hline
\end{tabular}

MODEL

In this study, we will focus on two models which are ARIMA and Linear Model to build our predictive model in calculating daily stock price for November 2020 . We use data from January to October 2020 to build the model and use the model to predict November 2020. We then compare the prediction model with the actual value.

(Auto-Regressive Integrated Moving Average) ARIMA

The first model that we will use is Auto-Regressive Integrated Moving Average (ARIMA). ARIMA is one of the forecasting models applied for future predictions using time series data. This model use linear functions on past financial data to predict future outcome. ARIMA model has demonstrated that it can outperform other techniques such as Exponential Smoothing in terms of accuracy and prediction (Siami-Namimi \& Siami-Namimi 2018). There is still a lot of researches that use ARIMA model to predict financial market movements since most of them believe that historical price data can be used to predict future price.

ARIMA model is specified by three order parameters: $p, d, q$. Parameter $p$ stands for order of auto regressive (AR) model, and $q$ represents the order of moving average (MA) model (Fattah et al. 2018). Paremeter $d$ is determine using the Augmented Dickey-Fuller (ADF) to test whether the time series is stationary (Benvenuto et al. 2020). We will use the autocorrelation function (ACF) and partial autocorrelation function (PACF) to determine the parameters of the ARIMA model. Lastly, we will choose the best ARIMA model based on the lowest Akaike Information Criterion (AIC). AIC can be denoted as:

$$
\mathrm{AIC}=-2 \log (\text { likelihood })+2 k
$$

where the number of parameters applied to model is $\mathrm{k}$. A lower AIC value means that the model is best and we do not want to overfit the models when we increase the parameters.

\section{Time Series Linear Model}

Linear model returns an equation that determined the relationship between the independent variables and the dependent variables as shown in Table 2 . We want to find the relationship between $Y$ and $X$ assuming that there is a linear relationship with time series. The linear model equation can be written as:

$$
Y_{t}=\theta_{1}+\theta_{2} X_{t}+\ldots+\theta_{n} X_{n}+\varepsilon_{t}
$$


where $X_{1}, X_{2}, \ldots X_{n}$ represent the independent variable while the coefficient $\theta_{1}, \theta_{2}, \ldots \theta_{n}$ represent the weights.

The different between general linear model with time series linear model is the assumption. In time series linear model, we assume that the independent variables might be related with time. Using time series linear model, we can look into the relationship between the independent variables that might have an effect on the dependent variables.

\section{RESULTS AND DISCUSSION}

DESCRIPTIVE STATISTICS

We start by looking at the descriptive statistical value.
Based on the skewness values in Table 3, there is a positive trend for FTSE 100 and negative trends for the other indices' prices which shows that the data might not be normally distributed. However, it is said that for normal distribution, the value of Kurtosis is equal to 3.0 (Anders 2018). Since all the kurtosis values are close to 3 , we can assume that the stock prices are normally distributed. Moreover, the mean and median indices are close, which is why we assume data to be symmetric. For this project, we will assume that the price data has a normal distribution based on the kurtosis, mean and median value.

TABLE 3. Descriptive statistics

\begin{tabular}{|c|c|c|c|c|}
\hline \multicolumn{5}{|c|}{ Closing price } \\
\hline Statistic & S\&P 500 & FTSE 100 & Nikkei & KLCI \\
\hline Mean & 3175 & 6250 & 22274 & 1502 \\
\hline Median & 3255 & 6083 & 22885 & 1516 \\
\hline Standard deviation & 299.127 & 627.510 & 2047.446 & 86.071 \\
\hline Skewness & -0.9344 & 0.9879 & -0.8045 & -1.0299 \\
\hline Kurtosis & 3.3758 & 3.2114 & 3.4486 & 3.4640 \\
\hline \multicolumn{5}{|c|}{ New cases } \\
\hline Statistic & US & UK & Japan & Malaysia \\
\hline Mean & 41970 & 5007.0 & 431.37 & 201.3 \\
\hline Median & 32477 & 1277.5 & 264.00 & 23.5 \\
\hline Standard deviation & 43280 & 7426.969 & 513.804 & 381.446 \\
\hline Skewness & 1.7268 & 1.7410 & 1.6960 & 2.4440 \\
\hline Kurtosis & 6.1258 & 4.8320 & 6.0689 & 9.1185 \\
\hline \multicolumn{5}{|c|}{ New deaths } \\
\hline Statistic & S\&P 500 & FTSE 100 & Nikkei & KLCI \\
\hline Mean & 866.3 & 183.8 & 6.252 & 1.119 \\
\hline Median & 915.0 & 38.5 & 4.5 & 0 \\
\hline Standard deviation & 692.744 & 275.074 & 6.714 & 2.042 \\
\hline Skewness & 0.5127 & 1.8184 & 1.2667 & 2.3247 \\
\hline Kurtosis & 2.7045 & 5.6422 & 4.2523 & 8.9863 \\
\hline
\end{tabular}


Table 3 also shows the descriptive statistics for new cases and new deaths. Based on the table, we can see that US has the highest mean for new cases and new death with 41,970 and 866.3 , respectively. Malaysia has the lowest mean which is 201.3 and1.119 for number of new cases and new deaths. All the countries have a positive trend in terms of number of cases and number of deaths based on the skewness and kurtosis which means that the data is not symmetric.

Figure 1 shows all four indexes closing price. We clearly see that the pattern of price index is almost the same for those four countries, where there is a drop in price in March 2020, after World Health Organization (WHO) declared COVID-19 as a global pandemic. All four countries also undergo lockdown at the end of March which means a reduction in economy activity that also have an impact on the index prices. Many sectors and industries were not able to operate at full capacity due to the introduction of Standard Operating Procedure (SOP), self-quarantine, work-from-home, and rotation to workfrom-office policy that reduce the production of materials.
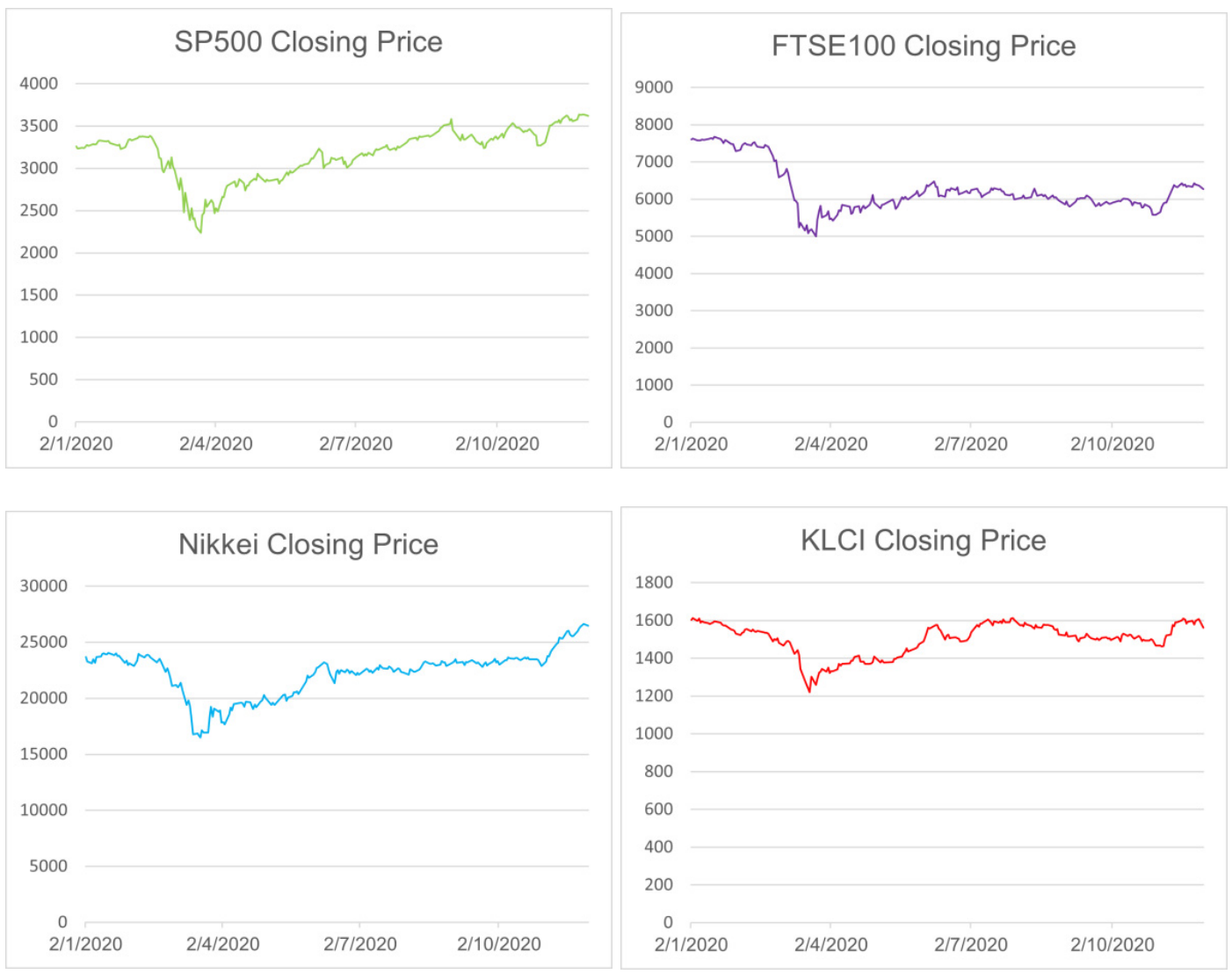

FIGURE 1. a) Price of S\&P 500 (US), b) Price of FTSE 100 (UK), c) Price of Nikkei 225

(Japan), and d) Price of KLCI (Malaysia) 
After March, we could say that the market is in recovering mode looking by the gradient of S\&P500 and Nikkei 225 prices. As for FTSE100 and KLCI, we could say the stock price is quite stagnant but towards the last quarter, all four indices become more stable. With the new finding patent on the COVID-19 vaccine developed by Pfizer and Germany's BioNTech that give more than $90 \%$ effective has breakthrough and give positive impact to the stock market.

From Figure 2, we can see that the number of COVID-19 cases started to grow after March 2020. But the positive cases and deaths trend for both Malaysia and Japan are small (Figure 2(b)) compare to US and UK
(Figure 2(a)). Therefore, we separated the two tables where US reach about 200,000 cases per day while Japan reaches only about 2,500 cases per day which is almost $1 \%$ cases per day compare to US.

One of the main reasons is because the number of populations in UK and US are higher compare to Malaysia and Japan. Another reason is we believe that at earlier stage, both Malaysia and Japan are better in managing COVID-19 cases compare to US and UK. The leaders from Malaysia and Japan also think that COVID-19 is a serious case compare to leaders in US and UK especially at the beginning of the year. However, in the last quarter of 2020, we can see a huge spike for all the countries.
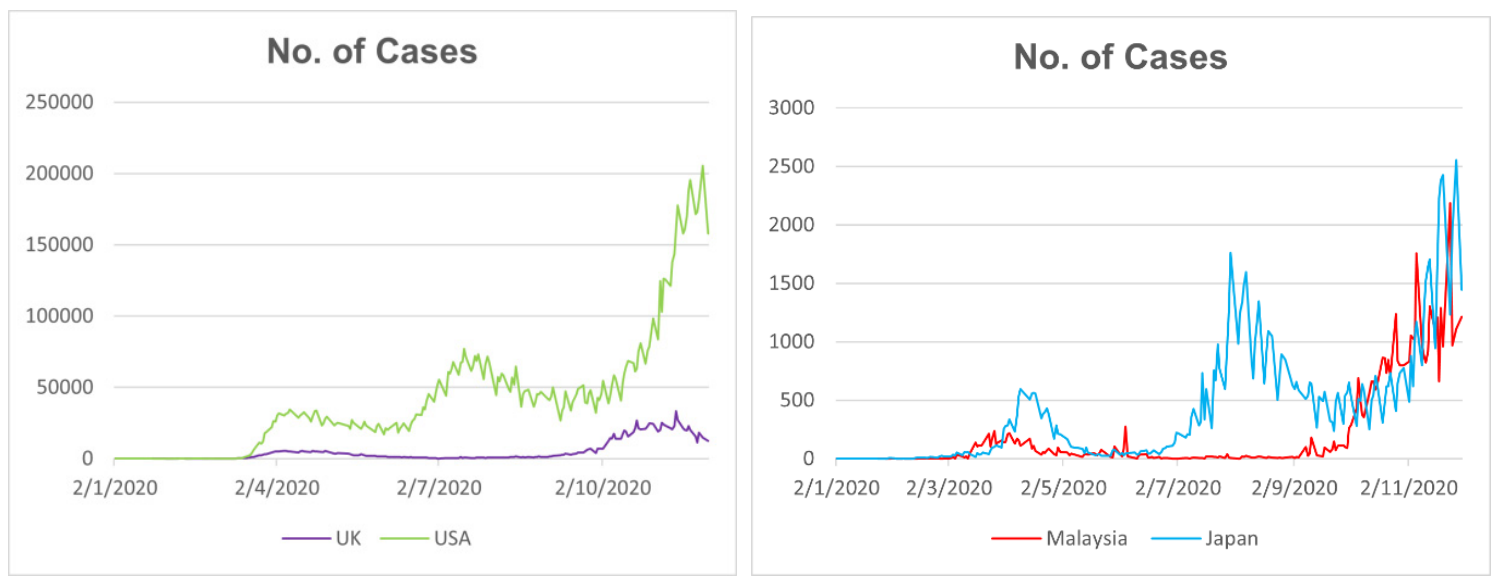

FIGURE 2. (a) COVID-19 Cases in UK and US, and (b) COVID-19 Cases in Malaysia and Japan

In Figure 3, we can see fluctuations in the number of deaths. In the earlier stage, around May and June, the huge spikes might be because most countries do not know how to deal with COVID-19. The number of deaths in July drop but then it started to increase in the last quarter of 2020. This might be because there was a huge spike in the number of cases where health sector could not accommodate COVID-19 patients. Malaysian graph is considered flatten for both cases and death since first quarter but started to increase in October with a high gradient for the cases figure.

From Figures 2 and 3, COVID-19 is still a main problem in all countries as we see an increase in number of cases in the last quarter of 2020. Most people did not expect this to happen as we thought that by the end of 2020, we manage to find vaccines and reduce the number of cases. As of right now, the number of cases were still large that some countries were planning to do another lockdown to reduce number of cases. 

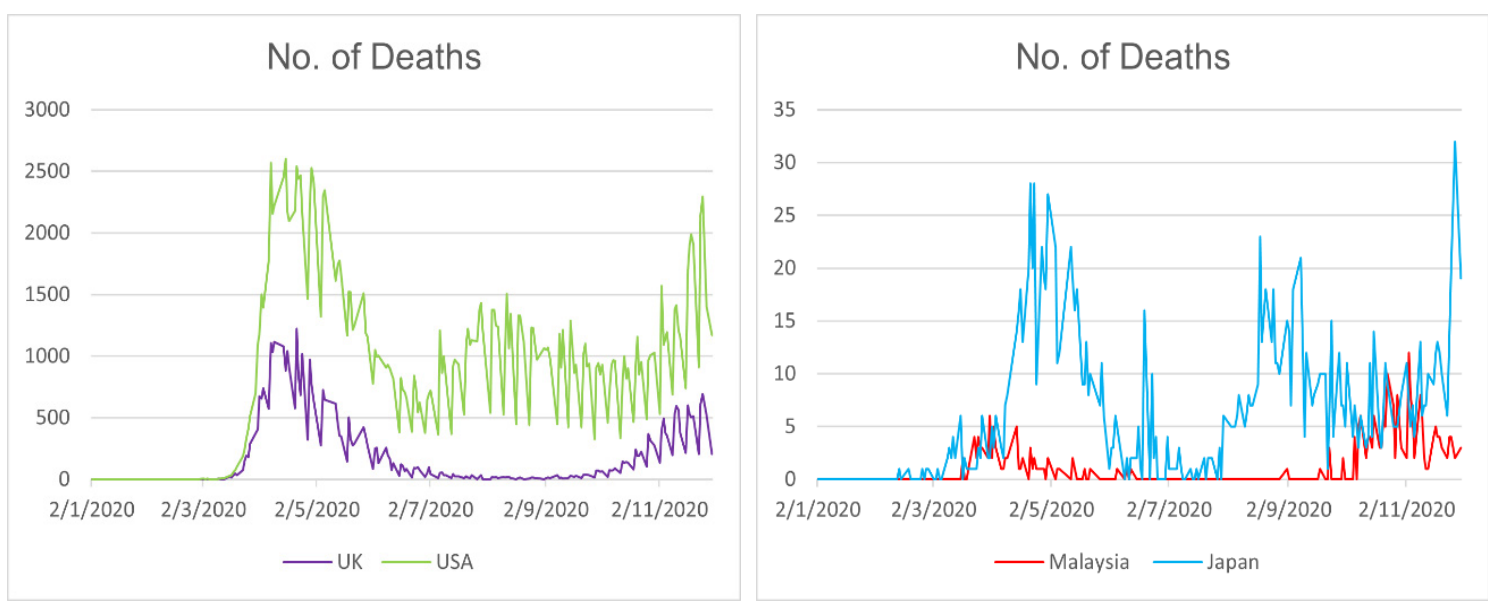

FIGURE 3. (a) COVID-19 Deaths in UK and US, and (b) COVID-19 Deaths in Malaysia and Japan

A correlation test is widely used as an initial step to evaluate the relationship between the stock market and a potential covariate. In this study, we use Pearson's Correlation Coefficient to study correlation between the stock closing price to the related and each of the COVID-19 variables, shown in Table 4. We calculate correlation between daily closing price and the daily
COVID-19 cases and deaths and highlight on the positive correlation between the number of cases and the number of deaths where the higher the number of COVID-19 cases, the higher number of deaths occurs. This might be due to the fact that the higher number of COVID-19 cases, health facilities were not able to accommodate patients thus increasing the number of deaths.

TABLE 4. Correlation for closing price with new cases and new deaths

\begin{tabular}{|c|c|c|c|c|c|c|c|}
\hline S\&P 500 & $\begin{array}{l}\text { Closing } \\
\text { price }\end{array}$ & New cases & $\begin{array}{l}\text { New } \\
\text { deaths }\end{array}$ & FTSE100 & $\begin{array}{c}\text { Closing } \\
\text { price }\end{array}$ & New cases & New deaths \\
\hline Price & 1.0 & 0.5062 & -0.0683 & Price & 1.0 & -0.2860 & -0.3563 \\
\hline New Cases & & 1.0 & 0.4615 & New Cases & & 1.0 & 0.3505 \\
\hline New Deaths & & & 1.0 & New Deaths & & & 1.0 \\
\hline Nikkei 225 & $\begin{array}{l}\text { Closing } \\
\text { price }\end{array}$ & New cases & $\begin{array}{l}\text { New } \\
\text { deaths }\end{array}$ & KLCI & $\begin{array}{l}\text { Closing } \\
\text { price }\end{array}$ & New cases & New deaths \\
\hline Price & 1.0 & 0.4517 & -0.0384 & Price & 1.0 & 0.1092 & -0.1797 \\
\hline New cases & & 1.0 & 0.3921 & New Cases & & 1.0 & 0.3505 \\
\hline New deaths & & & 1.0 & New Deaths & & & 1.0 \\
\hline
\end{tabular}


Based on the FTSE correlation, there is a negative relationship between closing price with COVID-19 cases and death. When the number of COVID-19 cases increases, the price of FTSE tends to drop. Even though the correlation value is not high, but we can see the impact of COVID-19 to the FTSE 100 closing price.

For the other three countries, closing price shows a positive correlation with new cases and negative correlation with new deaths. This means that an increase in number of COVID-19 cases will cause an increase to the price. From the death perspective, we can see a small negative impact on the number of deaths with the price of the index. This means that an increase in the new deaths, lower the price of the indexes. However, the impact of death in Japan and US is very small and close to zero.

In conclusion, we find that there exists a significant positive correlation between price and new cases in Japan and USA with value 0.45 and 0.51 , respectively. Increase in the number of cases will increase the closing price. However, there is no significant relationship with the number of deaths for the two countries. In the UK, there is a negative impact of COVID-19 cases and death on the FTSE closing prices and in Malaysia, there is a positive impact of COVID-19 cases but a negative impact of COVID-19 cases on the KLCI closing prices.

\section{PREDICTIVE ANALYSIS}

We construct a predictive model to evaluate the evident of relationship between stock price and the COVID-19 new cases and deaths. In line with the study objective, the predictive accuracy is compared with other forecast models for stock price value.

As mention earlier, we are using two models: ARIMA and Linear Regression Model. For ARIMA, we use three different number of observations for our training data and compare and best fit model for ARIMA, shown in Table 5. As for Linear Model, our in-sample data is from January 2020 until October 2020. The data in November 2020 were use as out-of-sample data and use as prediction.

TABLE 5. Training data for ARIMA Model

\begin{tabular}{cc}
\hline $\begin{array}{c}\text { Training data } \\
\text { (observation) }\end{array}$ & Date period \\
50 & Mid Aug - Oct 2020 \\
100 & June - Oct 2020 \\
453 & Jan - Oct 2020 \\
\hline
\end{tabular}

\section{ARIMA Model}

ARIMA is the most common time series prediction model in statistic model. Before we proceed to build the automate model, we performed stationary test using Augmented Dicky Fuller test for stationary by using adf.test function from tseries package. If $\mathrm{ADF}$ test has $\mathrm{p}$-value less than the 0.05 significant level indicating that the series is stationary.

For parameter estimations, the auto.arima function was used in R package to find the best fit ARIMA model to univariate time series based on either Akaike Information Criterion (AIC), or its small-sample equivalent (AICc) or Bayesian Information Criterion (BIC) value (Dhamo \& Puka 2010). Training error measure is explained in Table 6 , and the best ARIMA model for these 4 countries is using 50 training data as it gives value of Mean Absolute Percentage Error (MAPE) less than 2.0 for all the model which consider the error to be small, means high accuracy (Swamidass 2000) with lowest AIC value. The best ARIMA model according to the function gives 
$\operatorname{ARIMA}(1,0,0)$ for S\&P 500, FTSE and KLCI both have the same model with $\operatorname{ARIMA}(0,1,0)$ and Nikkei 225 with $\operatorname{ARIMA}(0,1,1)$. The best ARIMA model according to the function gives $\operatorname{ARIMA}(1,0,0)$ for S\&P 500, FTSE and KLCI both have the same model with $\operatorname{ARIMA}(0,1,0)$ and Nikkei 225 with ARIMA $(0,1,1)$.

TABLE 6. Training error measure

\begin{tabular}{|c|c|c|c|c|}
\hline Index & Measure & 50 Data & 100 Data & 453 Data \\
\hline \multirow[t]{3}{*}{ S\&P 500} & ARIMA & $\operatorname{ARIMA}(1,0,0)$ & $\operatorname{ARIMA}(1,1,1)$ & $\operatorname{ARIMA}(0,1,2)$ \\
\hline & MAPE & 1.016664 & 0.9746688 & 1.403417 \\
\hline & AIC & 535.93 & 1042.42 & 2189.95 \\
\hline \multirow[t]{3}{*}{ FTSE } & ARIMA & $\operatorname{ARIMA}(0,1,0)$ & $\operatorname{ARIMA}(1,1,1)$ & $\mathrm{v}(0,1,0)$ \\
\hline & MAPE & 0.9131754 & 0.9732676 & 1.374314 \\
\hline & AIC & 567.01 & 1153 & 2441.89 \\
\hline \multirow[t]{3}{*}{ Nikkei 225} & ARIMA & $\operatorname{ARIMA}(0,1,1)$ & $\operatorname{ARIMA}(1,1,1)$ & $\operatorname{ARIMA}(0,1,0)$ \\
\hline & MAPE & 0.6009058 & 0.8032497 & 1.333642 \\
\hline & AIC & 670.08 & 1388.62 & 2909.07 \\
\hline \multirow[t]{3}{*}{ KLCI } & ARIMA & $\operatorname{ARIMA}(0,1,0)$ & $\operatorname{ARIMA}(2,1,0)$ & $\operatorname{ARIMA}(0,1,0)$ \\
\hline & MAPE & 0.6393728 & 0.7159465 & 0.8701267 \\
\hline & AIC & 396 & 823.06 & 1694.83 \\
\hline
\end{tabular}

We now visualize all four indices forecast value based on the best fit ARIMA model in Figure 4. We can see the differences between the actual data and the predicted data. Using ARIMA, the model under predicts the stock returns for all four indexes where we can see most of the actual data do not fall within $80 \%$ (grey line) and 95\% (blue line) confidence interval.

In early November, the predicted value seems to be close to the actual value, and the actual value is within the interval but after that, the predicted value is far from the actual value especially for Nikkei 225 Index. KLCI Index shows that the actual value falls into the interval towards the end of November.
The longer the time, the actual price become more separated than the actual line. From this, we can see that using only 50 historical data is good enough to predict the price of index based on the confidence interval, but we want to improve our results by including additional information that might relate to the price. We will now look at the Linear Regression Model and include the number of cases and deaths as dependent variables in predicting the price of indexes.

\section{LINEAR REGRESSION MODEL}

To run this analysis, we use Time Series Linear Model (TSLM) function in R software. This model is similar as 
linear model function but is used for a time series data. We build a model to find relationship on stock index with both COVID-19 deaths and cases. The model is written as:

Price $=\theta_{1}+\theta_{2}$ New Death $+\theta_{3}$ New Case
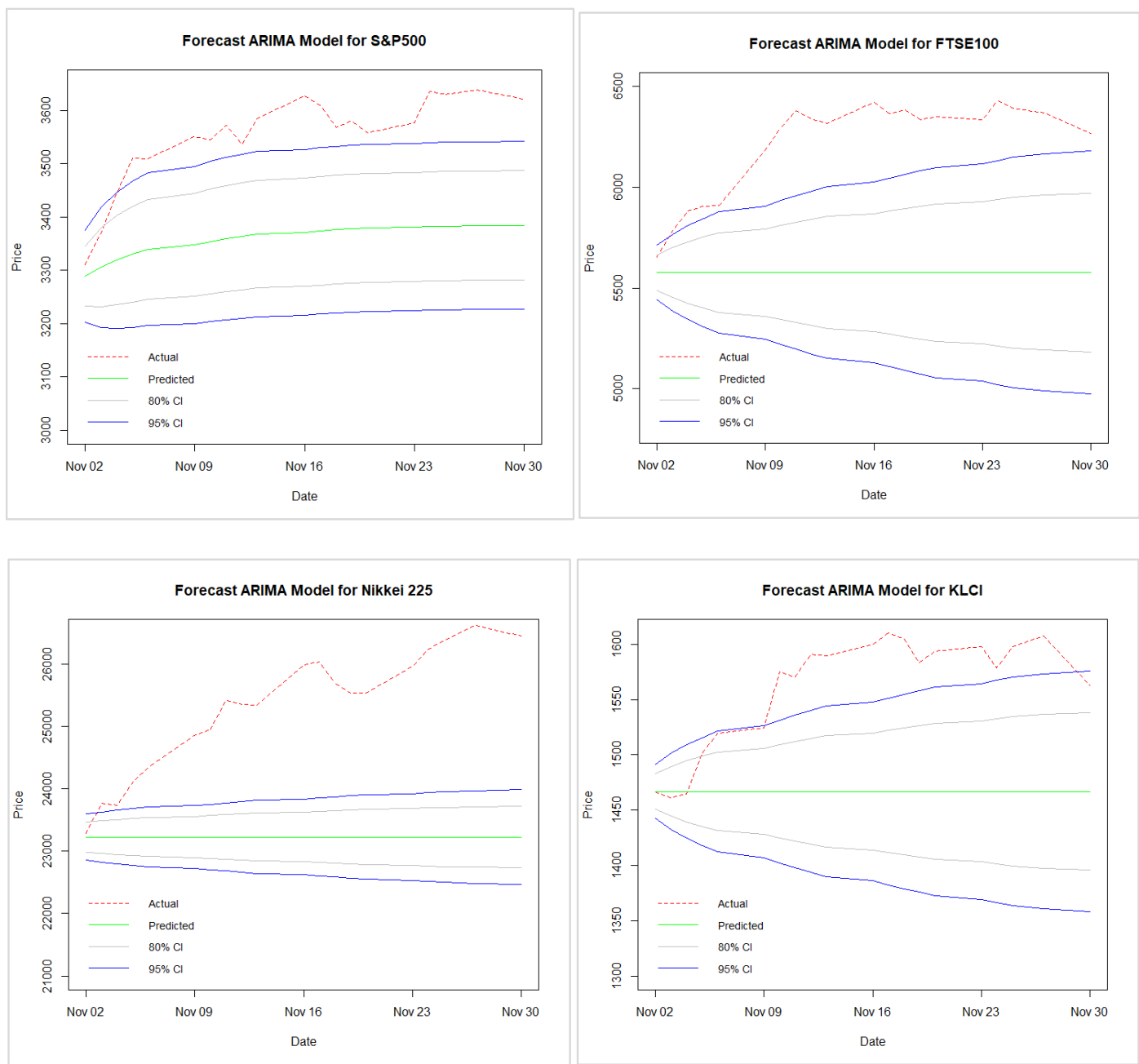

FIGURE 4. Forecast ARIMA Model

We will focus on two parameters in the regression statistical report, higher Adjusted R-squared value means, the added variable contributes to improve the model accuracy (Miles 2014) and lower p-value means the data obtain a statistically significant result (Westfall \& Young 1993).
S\&P 500 (USA)

Both cases and deaths variables are significant in predicting the stock price, shown by probability value with less than 0.05 . The adjusted R-squared indicates $27 \%$ of the variation in the output are explained by the input. The $\mathrm{p}$-value for this model is less than the pre-determined statistical significance level of 0.05 , hence the model is significant. 
Price $=3089+0.006727$ New Cases -0.1937 New Death

\begin{tabular}{|c|c|c|c|c|}
\hline Variable & Coefficient & Std. Error & t-Statistic & Probability \\
\hline Intercept & 3089 & 30.31 & 101.898 & $0 * * *$ \\
\hline Cases & 0.006727 & 0.0008227 & 8.177 & $0 * * *$ \\
\hline Death & -0.1937 & 0.02871 & -6.748 & $0 * * *$ \\
\hline Adjusted R-squared & \multicolumn{4}{|c|}{0.2763} \\
\hline F-Statistic & \multicolumn{4}{|c|}{$38.61(\mathrm{p}$-value $=0)$} \\
\hline
\end{tabular}

FTSE 100 (UK)

Both number of cases and death variables are significant in forecasting FTSE 100 stock price. Although the Adjusted
$\mathrm{R}$-squared value for the model shows $23 \%$ variation in predicting FTSE 100 price with significant p-value.

Price $=6499.00493-0.03665$ New Cases -0.75467 New Deaths

\begin{tabular}{lcccc}
\hline Variable & Coefficient & Std. Error & t-Statistic & Probability \\
\hline Intercept & 6499.00493 & 51.39662 & 126.448 & $0 * * *$ \\
Cases & -0.03665 & 0.00757 & -4.841 & $0 * * *$ \\
Death & -0.75467 & 0.15441 & -4.887 & $0 * * *$ \\
Adjusted R-squared & & 0.2318 & \\
F-Statistic & & $30.71(\mathrm{p}$-value $=0)$ & \\
\hline
\end{tabular}

Nikkei 225 (Japan)

Again, both variables are significant in determining Nikkei
225 stock price with $11 \%$ variation with p-value that is less than 0.05 .

Price $=21987.3769+1.4588$ New Cases -85.6424 New Death

\begin{tabular}{lcccc}
\hline Variable & Coefficient & Std. Error & t-Statistic & Probability \\
\hline Intercept & 21987.3769 & 42.84 & 54.840 & $0 * * *$ \\
Cases & 1.4588 & 0.3061 & 2.654 & $0 * * *$ \\
Death & -85.6424 & 28.46 & 1.846 & $0 * * *$ \\
Adjusted R-squared & & 0.11 & \\
F-Statistic & & 13.17 (p-value $=0)$ & \\
\hline
\end{tabular}




\section{KLCI (Malaysia)}

Although the probability value for cases is 0.0217 and closer to 0.05 , both variables are still significant in determining the KLCI price with value of adjusted $\mathrm{R}$-square of $11.83 \%$ variation and small $\mathrm{p}$-value.

Price $=1506.56615+0.09629$ New Cases -25.53901 New Deaths

\begin{tabular}{|c|c|c|c|c|}
\hline Variable & Coefficient & Std. Error & t-Statistic & Probability \\
\hline Intercept & 1506.56615 & 6.54685 & 230.121 & $0 * * *$ \\
\hline Cases & 0.09629 & 0.04161 & 2.314 & $0.0217 *$ \\
\hline Death & -25.53901 & 5.18755 & -4.923 & $0 * * *$ \\
\hline Adjusted R-squared & \multicolumn{4}{|c|}{0.1183} \\
\hline F-Statistic & \multicolumn{4}{|c|}{$14.22(\mathrm{p}$-value $=0)$} \\
\hline
\end{tabular}

We could say that our linear model, Price $=\theta_{1}+\theta_{2}$ New Death $+\theta_{3}$ New Case shows significant value in the predicted value. We then plot and compare our model in the next section.

MODEL COMPARISON

In this section, we compared both ARIMA and Linear
Model by calculate the error and plot the predicted value over the actual value. We compare on the error value as in Table 7 and conclude that Linear Model is the best fit as it shows the lowest MAPE value.

TABLE 7. Training error measure for linear model

\begin{tabular}{ccc}
\hline Index & Model & MAPE \\
\hline S\&P 500 & ARIMA & 1.016664 \\
& LM & 0.012557 \\
FTSE 100 & ARIMA & 0.9131754 \\
& LM & 0.026253 \\
Nikkei 225 & ARIMA & 0.600906 \\
& LM & 0.02129 \\
KLCI & ARIMA & 0.6393728 \\
& LM & 0.020213 \\
\hline
\end{tabular}


We could clearly see in the graph that ARIMA model is way too far from the actual value, even though through calculation gives minimal error value, and the value is considered acceptable since it lies within $85-90 \%$ of confidence interval. However, Linear Model is better a fit as it touches the actual value more than ARIMA predicted data in Figure 5 .
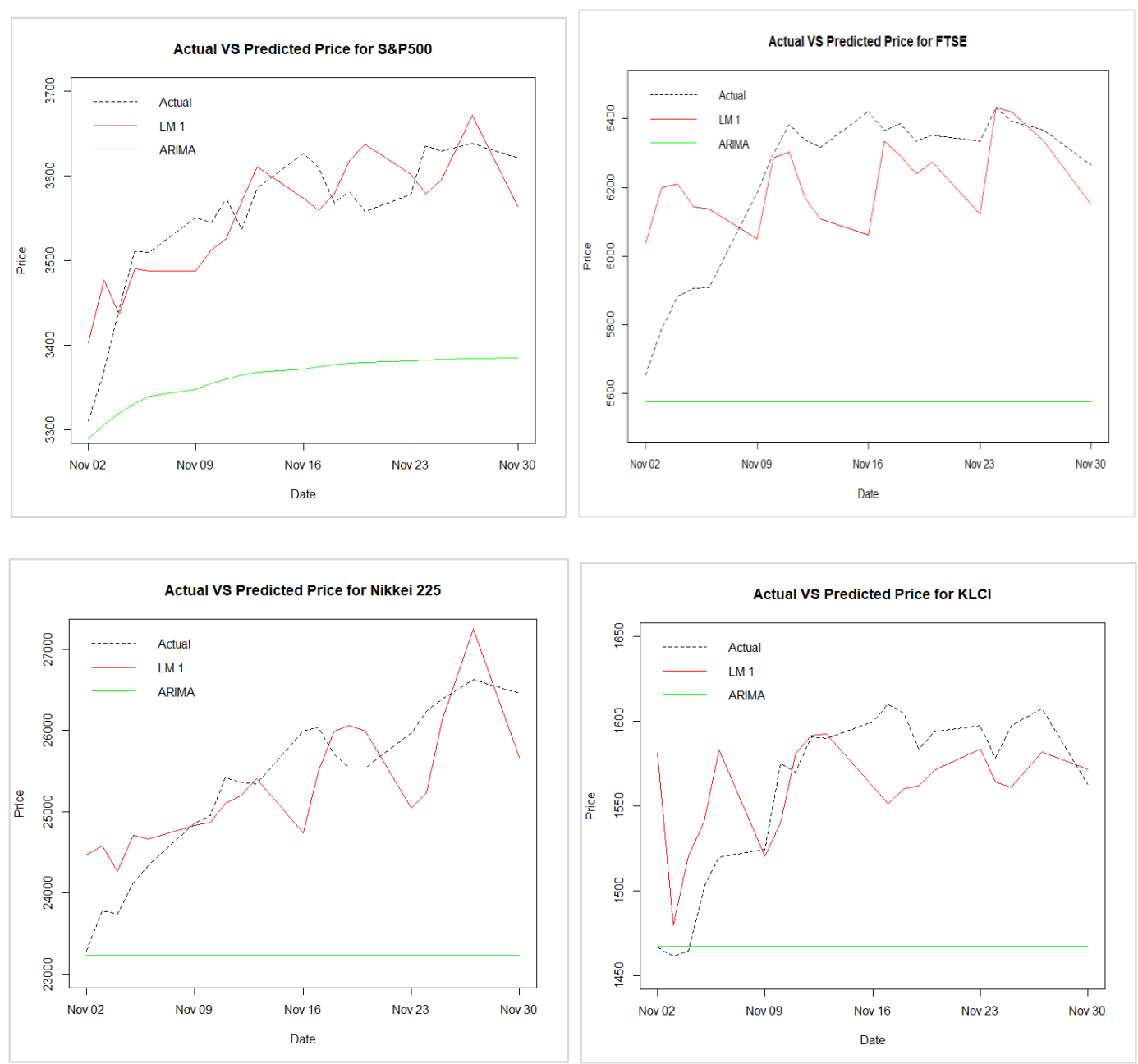

FIGURE 5. Actual vs predicted value for all models

\section{CONCLUSION}

The aim of this paper was to evaluate whether COVID-19 cases and deaths explain and predict the stock market in November 2020. We develop a model framework that evaluates the correlation and prediction on the index price.
We find that COVID-19 cases and death have contemporary relationships and predictive abilities on the abnormal stock prices. We also did compare on different models for the stock prediction and find out that the best fit model is to be linear regression over ARIMA. We could say that linear model work best in predicting all index price 
compare to ARIMA model. This result is similar to other studies that say COVID-19 has an impact on financial market including commodities that were assume to be safe (Ali et al. 2020), higher financial volatility as the number of affected countries increases (Albulescu 2020) and higher level of risk cause investors to suffer for short period of time (Zhang et al. 2020). These studies believe that COVID-19 does impact the financial market but we improve it by finding the relationship between the number of cases and deaths and its impact to the financial market and we found there is a relationship that relates both health and economics growth of a countries. The economic growth can be seen based on the index price.

Further studies can be performed by incorporating other variables such as economic growth, interest rate and inflation rate along with other COVID-19 related variables.

\section{ACKNOWLEDGEMENTS}

The authors thank Faculty of Science and Technology, UKM for supporting this work. The paper is funded by Universiti Kebangsaan Malaysia with project code GGPM-2020-016.

\section{REFERENCES}

Albulescu, C. 2020. Coronavirus and Financial Volatility: 40 Days of Fasting and Fear. https://dx.doi.org/10.2139/ ssrn.3550630.

Ali, M., Alam, N. \& Rizvi, S.A.R. 2020. Coronavirus (COVID-19) - An epidemic or pandemic for financial markets. Journal of Behavioral and Experimental Finance 27: 100341.

Anders, K. 2018. Laboratory Statistics: Methods in Chemistry and Health Sciences. 2nd ed. Elsevier. pp. 1-140.

Ariyo, A.A., Adewumi, A.O. \& Ayo, C.K. 2014. Stock price prediction using the ARIMA Model. UKSim-AMSS 16th International Conference on Computer Modelling and Simulation, IEEE. pp. 106-112.

Baker, S.R., Bloom, N., Davis, S.J., Kost, K., Sammon, M. \& Viratyosin, T. 2020. The unprecedented stock market reaction to COVID-19. The Review of Asset Pricing Studies 10(4): 742-758.

Benvenuto, D., Giovanetti, M., Vassallo, L., Angeletti, S. \& Ciccozzi, M. 2020. Application of the ARIMA model on the COVID-19 epidemic dataset. ELSEVIER Data in Brief. 29: 105340.

Cox, J., Greenwald, D. \& Ludvigson, S.C. 2020. What Explains the COVID-19 Stock Market. Working Paper 27784. National Bureau of Economic Research.

Dhamo, E. \& Puka, L. 2010. Using the R-package to forecast time series: ARIMA models and application. In International Conference Economic \& Social Challenges and Problems.
Engelhardt, N., Krause, M., Neukirchen, D. \& Posch, P.N. 2021. Trust and stock market volatility during the COVID-19 crisis. Financial Research Letter 38: 101873.

Erdem, O. 2020. Freedom and stock market performance during COVID-19 outbreak. Financial Research Letters 36: 101671.

Fattah, J., Ezzine, L., Aman, Z., Moussami, H. \& Lachhab, A. 2018. Forecasting of Demand using ARIMA model. International Journal of Engineering Business Management 10: $1-9$.

Investing.com. Access on December 20, 2020.

Keh, C.G. \& Tan, Y.T. 2021. COVID-19: The impact of government policy responses on economic activity and stock market performance in Malaysia. Jurnal Ekonomi Malaysia 55(1): 1-11.

Nicola, M., Alsafi, Z., Sohrabi, C., Kerwan, A., Al-Jabir, A., Iosifidis, C., Agha, M., Agha, R., 2020. The socioeconomic implications of the coronavirus and covid-19 pandemic: A review. International Journal of Surgery 78: 185-193.

Mazur, M., Dang, M. \& Vega, M. 2021. COVID-19 and the March 2020 stock market crash. Evidence from S\&P1500. Financial Research Letters 38: 101690.

Miles, J. 2014. R squared, adjusted R squared. In Wiley StatsRef: Statistics Reference Online. DOI: 10.1002/9781118445112.

Siami-Namini, S. \& Siami Namin, A. 2018. Forecasting Economics and Financial Time: ARIMA vs LSTM. arxiv: 1803.06386

Swamidass, P.M. 2000. Encyclopedia of Production and Manufacturing Management. Springer Science \& Business Media.

Topcu, M. \& Gulal, O.S. 2020. The impact of COVID-19 on emerging stock markets. Finance Research Letters 36: 101691.

Wagner, A. 2020. What the stock market tells us about the post-covid-19 world. Nature Human Behaviour 4: 440. doi:10.1038/s41562-020-0869-y.

Westfall, P.H. \& Young, S.S. 1993. Resampling-Based Multiple Testing: Examples and Methods for P-Value Adjustment. New York: John Wiley \& Sons.

Yagli, I. 2021. The impact of COVID-19 on emerging stock market volatility: Empirical evidence from Borsa Istanbul. Journal of Research in Economics, Politics \& Finance 5: 269-279.

Zhang, D., Hu, M. \& Ji, Q. 2020. Financial markets under the global pandemic of COVID-19. Finance Research Letters 36: 101528.

Department of Mathematical Sciences

Faculty of Science and Technology

Universiti Kebangsaan Malaysia

43600 UKM Bangi, Selangor Darul Ehsan

Malaysia

*Corresponding author; email: nurfiryal@ukm.edu.my

Received: 31 January 2021

Accepted: 12 May 2021 